\title{
Effect of genotype, finishing system, and sex on physiochemical characteristics of goat meat
} Efeito do genótipo, do sistema de terminação e do sexo, sobre as características físico-químicas da carne de cabritos Luciana RODRIGUES ${ }^{1 *}$, Heraldo César GONÇALVES², Brenda Batista Lemos MEDEIROS³,
Maurício Furlan MARTINS ${ }^{2}$, Cláudia Marie KOMIYAMA², Marleide Costa CAÑIZARES

\begin{abstract}
Seventy-eight kids of both sexes and five genotypes were used: Alpine, $1 / 2$ Boer $+1 / 2$ Alpine (1/2 BA), $3 / 4$ Boer $+1 / 4$ Alpine, $1 / 2$ Anglo-nubian $+1 / 2$ Alpine and "tricross" ( $1 / 2$ Anglo-nubian $+1 / 4$ Boer $+1 / 4$ Alpine) with initial average weight of $14.1 \pm 2.5$. The objective was to evaluate the effect of genotype, finishing system, and sex on the physiochemical characteristics of goat meat. Finishing systems were: ST1 - kid + dam in pasture and ST2 - weaned kid and feedlot. Kids in ST1 were kept in an area with Panicum maximum cv. Tanzania, and after grazing, water and mineral salt/mix were fed ad libitum to the animals. The animals in ST2 were confined in collective pens distributed according to genotypes and received diet with $16 \% \mathrm{CP}$ and $73 \% \mathrm{TDN}$. The values of $\mathrm{pH}$, $\mathrm{a}^{\star}$ (red content), Cooking Loss (CL), and Ether Extract (EE) percentage were influenced by genotype. Values for red content $\left(\mathrm{a}^{*}\right)$ and $\mathrm{L}^{\star}$ (brightness), CL and percentages of moisture, protein, EE, and ash were influenced by the finishing system. Longissimus dorsi muscle from animals $1 / 2$ BA exhibited better physiochemical characteristics. For greater tenderness and higher percentages of fat, consumers should choose female kid goat meat.
\end{abstract}

Keywords: chemical composition; goats; quality.

\section{Resumo}

Foram utilizados 78 cabritos de ambos os sexos e de cinco genótipos: raça Alpina, 1/2 Boer + 1/2 Alpina, 3/4 Boer + 1/4 Alpina, 1/2 Anglonubiana $+1 / 2$ Alpina e tricross (1/2 Anglo-nubiana + 1/4 Boer + 1/4 Alpina), com peso médio inicial de 14,1 $\pm 2,5 \mathrm{~kg}$. Objetivou-se avaliar os efeitos do genótipo, do sistema de terminação e do sexo sobre as características físico-químicas da carne. Os sistemas de terminação foram constituídos: ST1 - cabrito + mãe em pasto e ST2 - cabrito desmamado confinado. Os cabritos do ST1 foram mantidos em piquetes formados com Panicum maximum cv. Tanzânia e os do ST2 receberam dieta completa com 16\% PB e 73\% NDT. Os valores de pH, a* (teor de vermelho), Perda de Peso ao Cozimento (PPC) e porcentagem de Extrato Etéreo (EE) foram influenciados pelo genótipo. Os teores de vermelho $\left(\mathrm{a}^{*}\right)$ e $\mathrm{L}^{*}$ (luminosidade), PPC e porcentagens de umidade, proteína, EE e cinzas foram influenciados pelo sistema de terminação. O músculo longissimus dorsidos animais $1 / 2 \mathrm{BA}$ apresentou as melhores características físico-químicas. Se a preferência do consumidor for por uma carne mais macia e com maior teor de gordura, as fêmeas são mais indicadas.

Palavras-chave: composição centesimal; caprinos; qualidade.

\section{Introduction}

Goat meat presents a great market potential since it is characterized by a low intramuscular and subcutaneous fat content (BABIKER; EL KHIDIR; SHAFIE, 1990; JOHNSON et al., 1995, SHERIDAN; HOFFMAN; FERREIRA, 2003) indicating that it can be considered a nutritionally desirable alternative to red meat of other species (JOHNSON et al., 1995). However, in Southeast Brazil, its consumption is still limited due to low offer, lack of standardization of quality, and incentive deficiency.

In order to maintain high production and a high quality final product, a strategy would be exploring genetic diversity of goat species. Breeds with potential to increase profitability are those with heavier weights at maturity and genetic propensity for meat production, such as the Boer breed (SHRESTHA; FAHMY, 2007).
It is well know that goat genotype can have a significant effect on meat quality (DHANDA; TAYLOR; MURRAY, 2003; BESERRA et al., 2004; PRATIWI; MURRAY; TAYLOR, 2007; MADRUGA et al., 2008). In addition to genotype, animal performance and meat quality can be affected by the feeding system (TITI et al., 2000; SHERIDAN; HOFFMAN; FERREIRA, 2003).

The characteristics of meat from goats raised in intensive conditions have been studied more than those of goats raised in extensive conditions (BANSKALIEVA; SAHLU; GOETSCH, 2000; TSHABALALA et al., 2003).

According Del Campo et al. (2008), the challenge is to produce a finishing strategy to improve the product without modifying the peculiar characteristics acquired during extensive

\section{Received 6/8/2010}

Accepted 15/11/2010 (004964)

${ }_{1}$ Departamento de Produção Animal, Faculdade de Medicina Veterinária e Zootecnia, Universidade Estadual Paulista - Unesp, Rua João Matheus Danton, 74,

Vila Vendramini, CEP 18213-310, Itapetininga, SP, Brasil, e-mail:llucianarr@gmail.com

2 Departamento de Produção Animal, Faculdade de Medicina Veterinária e Zootecnia, Universidade Estadual Paulista - UNESP, Distrito de Rubião Jr, s/n, CEP 18618-970, Botucatu, SP, Brasil

${ }^{3}$ Faculdade de Engenharia Agrícola, Universidade de Campinas - UNICAMP, Barão Geraldo, CEP 13083-875, Campinas, SP, Brasil

${ }^{4}$ Instituto Federal de Educação, Ciência e Tecnologia do Rio Grande do Sul - IFRS, Campus Bento Gonçalves, CEP 95700-000, Bento Gonçalves, RS, Brasil

*Corresponding author 
grazing conditions (low-cost production and healthy meat for human consumption) and without compromising the animal welfare or the environment. Finishing systems in cattle have been extensively studied over the years with varied results on carcass traits and meat quality. Many studies have compared the meat tenderness and color of animals from extensive systems to those fed concentrated diet (FRENCH et al., 2000; REALINI et al., 2004). Many other studies reported no differences in quality and acceptability in meat from animals finished on pastures and concentrates (FRENCH et al., 2001; VESTERGAARD et al., 2000). This variability in results indicates that further research is necessary to establish the reasons for these differences.

The objective of this work was to study the influence of genotype, finishing system, and sex on physiochemical characteristics of goat longissimus dorsi meat.

\section{Material and methods}

Seventy-eight goat kids of both sexes from five genotypes were used and were divided into two finishing systems (Table 1).

After birth, the goat kids were housed in pens together with their dams and were fed hay and concentrate ad libitum, while the dams had free access to pasture. After 60 days of age, they were divided into two finishing systems: ST1 - goat kid + dam in pasture and ST2 - weaned goat kid and feedlot.

Ten paddocks of approximately $550 \mathrm{~m}^{2}$ established with Panicum maximum cv. Tanzania were used. The period of occupation of each paddock was of three days, with rest of 27 days. Each paddock had an automatic drinking fountain and a shadowed rest area of free access. Goat kids from finishing system 1 were kept on pasture from 9 AM to 5 PM; after the grazing period, they were housed in pens and were offered water and mineral salt ad libitum.

Animals of finishing system 2 were confined in 5 collective pens in according to genotype and had free access to water.

The complete diet offered ad libitum to animals of finishing system 2 was composed of $30 \%$ oat hay, $30 \%$ corn grain ground, $28 \%$ soybean meal, $8 \%$ wheat meal, $1 \%$ limestone, $1 \%$ dicalcium phosphate, and 2\% mineral supplement. Goat kids received two daily meals, at $8 \mathrm{AM}$ and $4 \mathrm{PM}$.

The specific mineral supplement for goats (amount.kg-1 of product) was composed of sulfur $200 \mathrm{~g}$, magnesium $150 \mathrm{~g}$, zinc $47210 \mathrm{mg}$, iron $27000 \mathrm{mg}$, copper $20000 \mathrm{mg}$, manganese $1200 \mathrm{mg}$, cobalt $1400 \mathrm{mg}$, iodine $1250 \mathrm{mg}$, and selenium $315 \mathrm{mg}$.
Chemical analysis of complete diet and forage was performed using the methods described by Silva and Queiroz (2006) and is presented in Table 2.

Goat kids slaughter occurred one week after they had completed 120 days of age. Animals were slaughtered in a commercial slaughterhouse after a 16 hours solid fasting. The average age was of $128.4 \pm 7.9$ days, and they were slaughtered and dressed following normal commercial procedures.

For analyses, samples of longissimus dorsi muscle were removed from the loins from the left half carcasses after separation of commercial cuts.

Muscle $\mathrm{pH}$ was measured through direct method using a $\mathrm{pH}$ meter (INGOLD-WTW-pH 91) with a glass electrode probe inserted in longissimus dorsi muscle in the lumbar area after storing the carcasses for a chilling period of 24 hours at $1-4{ }^{\circ} \mathrm{C}$.

Color was measured 24 hours after slaughter using a portable colorimeter Minolta CR400. The meter was calibrated using a black and white tile. Color was expressed in terms of CIE values for lightness $\left(L^{*}\right)$, redness $\left(a^{\star}\right)$, and yellowness $\left(b^{*}\right)$.

The water holding capacity was measured using the method described by Hamm (1960). WHC was expressed as percentage of drip loss, calculated as $\mathrm{WHC} \%=($ initial weight - final weight)/initial weight.

The same piece of muscle was used for shear force, color, and cooking loss measurements. Each piece of steak was placed in a plastic bag and cooked in a thermostatically controlled

Table 2. Chemical composition of complete diet and forage.

\begin{tabular}{lcr}
\hline \multicolumn{1}{c}{ Chemical composition } & Complete diet & Forage \\
\hline Dry matter (\%) & 94.59 & 24.31 \\
Mineral matter (\%) & 9.27 & 3.39 \\
Crude protein (\%DM) & 16.47 & 12.91 \\
Ether extract (\%DM) & 3.10 & 1.48 \\
Total carbohydrates (\%DM) & 70.82 & 82.22 \\
Neutral detergent fiber (\%DM) & 25.14 & 66.46 \\
Ácid detergent fiber (\%DM) & 15.17 & 40.93 \\
Non fiber carbohydrates (\%DM) ${ }^{2}$ & 38.14 & 15.22 \\
Total digestible nutrients (\%DM) & 73.77 & 66.34 \\
Metabolizable energy(Mcal.kg-1 DM) & 3.63 & 2.39 \\
Calcium (\%DM) & 2.66 & 0.85 \\
Phosphorus (\%DM) & 1.72 & 0.45 \\
\hline
\end{tabular}

${ }^{1}$ Obtained from the equation proposed by SNIFFEN et al. (1992). ${ }^{2}$ Obtained from the equation proposed by NRC (2001). ${ }^{3}$ Obtained from estimative of TDN and by the relations: $1 \mathrm{~kg}$ of NDT $=4.409 \mathrm{Mcal}$ of DE and ME $=81.7 \% \mathrm{DE}(\mathrm{NATIONAL} \ldots, 2001)$.

Table 1. Distribution of animals according to genotype, finishing system, and sex.

\begin{tabular}{|c|c|c|c|c|c|}
\hline \multirow[b]{3}{*}{ Genotype } & \multicolumn{4}{|c|}{ Finishing system } & \multirow[b]{3}{*}{ Total } \\
\hline & \multicolumn{2}{|c|}{ Goat kid + dam in pasture (ST1) } & \multicolumn{2}{|c|}{ Weaned goat kid and feedlot (ST2) } & \\
\hline & Male & Female & Male & Female & \\
\hline Alpine & 4 & 3 & 3 & 3 & 13 \\
\hline $1 / 2$ Anglo-nubian $+1 / 2$ Alpine & 4 & 3 & 5 & 3 & 15 \\
\hline $1 / 2$ Boer $+1 / 2$ Alpine & 4 & 3 & 3 & 4 & 14 \\
\hline $3 / 4$ Boer $+1 / 4$ Alpine & 3 & 6 & 4 & 5 & 18 \\
\hline "tricross"1 & 4 & 5 & 5 & 4 & 18 \\
\hline Total & 19 & 20 & 20 & 19 & 78 \\
\hline
\end{tabular}

"'tricross" - 1/2 Anglo-nubian + 1/4 Boer + 1/4 Alpine. 
water bath at $85^{\circ} \mathrm{C}$ for 45 minutes. Cooked samples were taken from the bag, dried with paper towel to remove excess surface moisture, and held at constant temperature. Cooking loss was evaluated by weight changes before and after cooking, expressed as percentage of the initial weight of the sample. (HONIKEL, 1998). A minimum of three samples with $1 \times 1 \times 2 \mathrm{~cm}$ were obtained from each steak (FRONING; BABJI; MATHER, 1978). Each sample was sheared perpendicular to the grain of the muscle fiber using a Warner-Bratzler shear blade coupled to a texturemeter (Texture Analyzer TA-XPLUS-30) with a triangular whole cut to determine the peak force $\left(\mathrm{kgf}_{\mathrm{cm}} \mathrm{cm}^{-2}\right)$ to shear the samples (AMERICAN..., 1995). An average shear force was calculated and recorded for each steak.

The chemical composition was determined using the procedures described by Association... (2000).

The experimental design for the determination of physiochemical characteristics was a $5 \times 2 \times 2$ factorial with genotype, finishing system, and sex as dependent variables. Data were analyzed using statistical analyses and general linear models procedure in SAS (1999), according to the following model:

where: $Y_{i j k l}=$ characteristic evaluated in animal 1 in terms of sex k, genotype $j$ and submitted to finishing system i; $\mu=$ constant inherent to observations $Y_{i j k l} ; F S_{i}=$ effect of finishing system, where $\mathrm{i}=1$ : goat kid + dam on pasture and 2: weaned goat kid and feedlot; $G_{j}=$ effect of genotype j, where $j=1$ : Alpine breed, 2: 1/2 Boer $+1 / 2$ Alpine, 3: 3/4 Boer $+1 / 4$ Alpine, 4: $1 / 2$ Anglo-nubian + 1/2 Alpine, 5: "tricross" ( $1 / 2$ Anglonubian $+1 / 4$ Boer $+1 / 4$ Alpine); $S_{k}=$ effect of sex $\mathrm{k}$, where $=1$ : male and 2: female; $F S^{*} G_{i j}=$ effect of interaction of finishing system $i$ and genotype j; $F S^{\star} S_{i k}=$ effect of interaction of finishing system i and sex k; $G^{*} S_{k j}=$ effect of interaction of sex k and genotype $\mathrm{j} ; e_{i j k l}=$ error associated to observation $Y_{i j k l}\left(0, \sigma_{\mathrm{e}}^{2}\right)$.

\section{Results and discussion}

The effects of genotype, finishing system, and sex on parameters of final $\mathrm{pH}$ and color $\left(\mathrm{L}^{\star}, \mathrm{a}^{\star}\right.$ and $\left.\mathrm{b}^{\star}\right)$ of goat kids longissimus dorsi muscle are shown in Table 3.

Mean values of final $\mathrm{pH}$ varied from 5.62 to 6.02 , which are in accordance with data from the literature on goat meat: 5.97 to 6.32 (BESERRA et al., 2001), 5.96 to 6.03 (MADRUGA et al., 2005), and which corroborates the statement that $\mathrm{pH}$ of goat meat is higher than that of red meat of other species (LAWRIE, 2005).

Final $\mathrm{pH}$ was influenced by genotype, and the $1 / 2 \mathrm{AA}$ and $1 / 2 \mathrm{BA}$ animals presented higher values compared with other genotypes (Table 3 ). These results can be attributed to different responses of pre-slaughter handling stress for each genotype indicating that, possibly, the $1 / 2 \mathrm{AA}$ and $1 / 2 \mathrm{BA}$ animals were more susceptible to some type of pre-slaughter handling stress. According to Immonen, Ruusunen and Puolanne (2000), muscle glycogen is the main metabolic substrate responsible for post mortem lactic acid accumulation and thus for normal $\mathrm{pH}$ decrease. Results obtained in the present study are in accordance with those found by Swan et al. (1998), who evaluating physical and chemical properties of goat meat raised on pasture observed a final pH of 6.04 for animals of Boer breed and 5.78 for Boer $\times$ Cashmere crosses. Webb, Casey and Simela (2005) in a review article on goat meat quality suggest that the ultimate $\mathrm{pH}$ values are generally highly prone to stress.

The $L^{*}$ (lightness) value showed significant differences among the finishing systems studied. Animals in the feedlot finishing system had higher values (Table 3 ), which is consistent with those reported by Schroeder et al. (1980) that evaluated feedlot cattle meat and verified higher lightness values in the meat of those animals than those of animals finished on pasture. However, such values are not in accordance with other findings of Johnson and McGowan (1998), who found that the finishing system did not influence $\mathrm{L}^{\star}$ values.

The mean value for the $\mathrm{a}^{*}$ (redness) was 12.20 and showed significant differences among the genotype and finishing system. $1 / 2$ AA animals presented higher redness values compared with "tricross" animals. This result can be attributed to final $\mathrm{pH}$ value observed in $1 / 2 \mathrm{AA}$ animals (6.02) when compared with "tricross" (5.58). According to Aberle et al. (1994), higher $\mathrm{pH}$ in 24 hours postmortem results in darker meat (higher redness). In the present study, the variation in redness $\left(\mathrm{a}^{*}\right)$ value can be related to the capacity of genotype to influence proportion among the myoglobin forms (desoximyoglobin and oxymyoglobin). Similar to the findings in the present study, a significant effect of genotype on goat meat color has been reported by Monte et al. (2007) and Madruga et al. (2008).

Goat kids finished on pasture presented higher values of redness $\left(\mathrm{a}^{*}\right)$ compared with those of feedlot animals, in accordance with Priolo, Micol and Agabriel (2001), who, in a review article on the effect of feeding systems based on grass on meat color, concluded that the meat of animals finished on pasture is darker (higher redness) than the meat of animals finished with concentrates, associated to high final $\mathrm{pH}$. However, in the present study, the final $\mathrm{pH}$ of the two finishing systems was similar indicating that the differences are probably due to

Table 3. Means for $\mathrm{pH}, \mathrm{L}^{\star}$ (lightness), $\mathrm{a}^{\star}$ (redness), and $\mathrm{b}^{\star}$ (yellowness), in longissimus dorsi muscle from goats, according to genotype, finishing system, and sex.

\begin{tabular}{|c|c|c|c|c|}
\hline & \multicolumn{4}{|c|}{ Parameters } \\
\hline & $\mathrm{pH}$ & $\mathrm{L}^{*}$ & $\mathrm{a}^{*}$ & $\mathrm{~b}^{*}$ \\
\hline \multicolumn{5}{|l|}{ Genotype } \\
\hline Alpina & $5.62^{\mathrm{b}}$ & 36.93 & $12.30^{\mathrm{ab}}$ & 3.21 \\
\hline $1 / 2$ Anglo-nubian $+1 / 2$ Alpine & $6.02^{\mathrm{a}}$ & 36.10 & $12.60^{\mathrm{a}}$ & 2.76 \\
\hline $1 / 2$ Boer $+1 / 2$ Alpine & $5.89^{\mathrm{a}}$ & 37.31 & $11.76^{\mathrm{ab}}$ & 3.03 \\
\hline $3 / 4$ Boer $+1 / 4$ Alpine & $5.66^{\mathrm{b}}$ & 36.97 & $12.56^{\mathrm{ab}}$ & 3.13 \\
\hline "Tricross" & $5.58^{\mathrm{b}}$ & 36.19 & $11.76^{\mathrm{b}}$ & 3.59 \\
\hline \multicolumn{5}{|l|}{ Finishing system } \\
\hline Goat kid + dam on pasture (ST1) & 5.77 & $35.56^{\mathrm{b}}$ & $12.47^{\mathrm{a}}$ & 2.98 \\
\hline Goat kid weaned and feedlot (ST2) & 5.74 & $37.84^{\mathrm{a}}$ & $11.93^{\mathrm{b}}$ & 3.31 \\
\hline \multicolumn{5}{|l|}{ Sex } \\
\hline Male & 5.77 & 36.84 & 12.17 & 3.15 \\
\hline Female & 5.74 & 36.56 & 12.23 & 3.14 \\
\hline Mean & 5.75 & 36.70 & 12.20 & 3.14 \\
\hline Coefficient of variation & 4.02 & 3.55 & 6.99 & 26.57 \\
\hline
\end{tabular}


the more intense physical activity and iron concentration in the muscle of animals finished on pasture, in cattle meat, according to Vestergaard, Okabjerg and Henckel (2000). When evaluating the quality of lamb meat, Cañeque et al. (2003) observed darker meat in animals on pasture.

As show in Table 4, water holding capacity ranged from 22 to $30 \%$, wich is within the normal range for goat meat (DHANDA; TAYLOR; MURRAY, 2003; TODARO et al., 2004), and showed significant differences among the genotypes. $3 / 4$ BA Animals presented lesser loss of nutritional value of meat due to the smallest amount of exudate. According to Hamm (1982), water holding capacity is caused, mainly, by water immobilization inside the miofibrilar system. The water holding capacity data, however, is in accordance with other findings of Kadim et al. (2003), who verified in Oman kid goat meat values of WHC in longissimus dorsi muscle from 33.3 to $41.0 \%$.

Longissimus dorsi muscle from kid goats of Alpine breed had higher Cooking Loss (CL) compared with that of $1 / 2 \mathrm{BA}$ and $3 / 4 \mathrm{BA}$ animals, and similar to that of $1 / 2 \mathrm{AA}$ and tricross animals (Table 4). Cooking loss was influenced by water holding capacity and, as seen in Table 4, Alpine breed presented the lowest water holding capacity, and consequently they had greater volume of sarcoplasmic fluids and higher cooking loss. Kannan, Kouakou and Gelaye (2001) evaluated Spanish goats in pasture, fed supplemented diet, and slaughtered at 8 months, and they verified a CL of $14.2 \%$. However, differences in cooking loss, observed by several authors, can be attributed to different cooking times and temperatures and final $\mathrm{pH}$.

Longissimus dorsi muscle from animals finished on pasture had higher cooking loss than that of 1 . dorsi from feedlot goats (Table 4), probably due to greater volume of sarcoplasmic fluids in longissimus dorsi muscle. Cooking loss data also differs from the results found by Schönfeldt et al. (1993), who observed lower CL in goats than in lambs, and they attributed those results to the largest amount of fat present in the lamb muscle.

Means for shear force varied from 6.21 to $7.40 \mathrm{kgf.cm}^{-2}$ and showed significant differences between the sexes (Table 4). Johnson et al. (1995), Dhanda, Taylor and Murray (1999) and Ryan et al. (2007) found averages of 6.0; 4.3 and 5.8 kgf.cm ${ }^{-2}$, respectively. In the literature, great variations are found in the results from different authors, and they can be attributed to differences in nutrition, age, cooking time and temperature, and final $\mathrm{pH}$. In this study, females presented lower values of shear force, when compared to males. Investigating sex and castration effects on bovine meat composition, Purchas (1991) concluded that a high final $\mathrm{pH}$ in bulls was an important factor in meat tenderness. However, in the present study, no difference was observed between the sexes for final $\mathrm{pH}$ value, and the less tenderness observed in the meat of males can be attributed to the smallest amount of covering fat thus becoming more susceptible to cooking shortening and less tenderness after cooking. Johnson et al. (1995) and Simela, Webb and Frylinck (2004) concluded that the female goat meat is more tenderness compared with the meat of males of same species.

Moisture percentage varied (74.63-76.37\%) and showed significant differences among the genotypes and finishing systems (Table 5), which is in agreement with the results found by Babiker, El Khidir and Shafie (1990); Dhanda, Taylor and Murray (2003); however these values are higher than those found by Dias et al. (2008). $1 / 2$ AA animals presented higher percentage of moisture compared with $1 / 2 \mathrm{BA}$ and "tricross" genotypes, and they were similar to that of Alpine breed and $3 / 4$ BA animals. According to Lawrie (2005), the least understood intrinsic factor that affects muscle constitution is individual variation between animals. Even between animals of same sex, considerable differences are found in moisture percentages and intramuscular fat.

Longissimus dorsi muscle from animals finished on pasture had higher moisture percentage compared with that of feedlot animals (Table 5). This is in agreement with the findings of Mtenga and Kitaly (1990), who reported that longissimus

Table 4. Means for Water Holding Capacity (WHC), Cooking Loss (CL), and shear force (SF) in longissimus dorsi muscle from goats, according to genotype, finishing system, and sex.

\begin{tabular}{|c|c|c|c|}
\hline & \multicolumn{3}{|c|}{ Parameters } \\
\hline & WHC (\%) & CL (\%) & SF $\left(\mathrm{kgf.cm}{ }^{-2}\right)$ \\
\hline \multicolumn{4}{|l|}{ Genotype } \\
\hline Alpine & $22.62^{c}$ & $35.85^{\mathrm{a}}$ & 6.90 \\
\hline $1 / 2$ Anglo-nubian $+1 / 2$ Alpine & $25.73^{\mathrm{bc}}$ & $35.28^{\mathrm{ab}}$ & 7.40 \\
\hline $1 / 2$ Boer $+1 / 2$ Alpine & $27.15^{\mathrm{ab}}$ & $33.69^{b c}$ & 6.77 \\
\hline $3 / 4$ Boer $+1 / 4$ Alpine & $30.77^{\mathrm{a}}$ & $33.34^{c}$ & 7.01 \\
\hline "Tricross" & $26.92^{\mathrm{b}}$ & $35.20^{\mathrm{abc}}$ & 6.21 \\
\hline \multicolumn{4}{|l|}{ Finishing system } \\
\hline Goat kid + dam on pasture (ST1) & 26.53 & $36.23^{\mathrm{a}}$ & 6.89 \\
\hline Weaned goat kid and feedlot (ST2) & 26.74 & $33.01^{\mathrm{b}}$ & 6.82 \\
\hline \multicolumn{4}{|l|}{ Sex } \\
\hline Male & 26.08 & 34.70 & $7.22^{\mathrm{a}}$ \\
\hline Female & 27.20 & 34.65 & $6.49^{\mathrm{b}}$ \\
\hline Mean & 26.64 & 34.67 & 6.86 \\
\hline Coefficient of variation & 14.11 & 5.58 & 21.03 \\
\hline
\end{tabular}

Means followed by different letter differ statistically by Tukey test $(\mathrm{p}<0.05)$.

Table 5. Means for moisture (MOI), Crude Protein (CP), Ether Extract (EE), and ash in longissimus dorsi muscle from goats, according to genotype, finishing system, and sex.

\begin{tabular}{|c|c|c|c|c|}
\hline & \multicolumn{4}{|c|}{ Parameters (\%) } \\
\hline & MOI & $\mathrm{CP}$ & $\mathrm{EE}$ & Ash \\
\hline \multicolumn{5}{|l|}{ Genotype } \\
\hline Alpine & $75.75^{\mathrm{ab}}$ & 22.16 & $1.17^{\mathrm{c}}$ & 1.05 \\
\hline $1 / 2$ Anglo-nubian $+1 / 2$ Alpine & $76.13^{\mathrm{a}}$ & 22.00 & $1.43^{\mathrm{bc}}$ & 1.07 \\
\hline $1 / 2$ Boer $+1 / 2$ Alpine & $75.11^{\mathrm{b}}$ & 22.51 & $2.21^{\mathrm{a}}$ & 1.06 \\
\hline $3 / 4$ Boer $+1 / 4$ Alpine & $75.34^{\mathrm{ab}}$ & 22.00 & $1.65^{\mathrm{b}}$ & 1.09 \\
\hline “Tricross" & $75.17^{\mathrm{b}}$ & 22.12 & $1.54^{\mathrm{bc}}$ & 1.05 \\
\hline \multicolumn{5}{|l|}{ Finishing system } \\
\hline Goat kid + dam on pasture (ST1) & $76.37^{\mathrm{a}}$ & $21.60^{\mathrm{b}}$ & $1.18^{\mathrm{b}}$ & $1.05^{\mathrm{b}}$ \\
\hline Weaned goat kid and feedlot (ST2) & $74.63^{\mathrm{b}}$ & $22.72^{\mathrm{a}}$ & $2.02^{\mathrm{a}}$ & $1.08^{\mathrm{a}}$ \\
\hline \multicolumn{5}{|l|}{ Sex } \\
\hline Male & 75.68 & 22.11 & $1.35^{\mathrm{b}}$ & 1.07 \\
\hline Female & 75.32 & 22.21 & $1.86^{\mathrm{a}}$ & 1.06 \\
\hline Mean & 75.50 & 22.16 & 1.60 & 1.06 \\
\hline Coefficient of variation & 1.28 & 3.96 & 24.22 & 5.32 \\
\hline
\end{tabular}

Means followed by different letter differ statistically by Tukey test $(\mathrm{p}<0.05)$. 
dorsi muscle of kid goats on pasture without supplementation presented greater moisture compared to animals with supplementation.

Longissimus dorsi muscle from feedlot-finished animals had higher percentage of crude protein compared with that of animals finished on pasture. These results indicate that feedlotfinished animals responded to nutritional plan depositing more muscular protein (Table 5).

The ether extract content showed significant differences among the genotype, finishing system, and sex (Table 5). The values are lower to those found by Babiker, El Khidir and Shafie (1990) for goats slaughtered at $35 \mathrm{~kg}$ live weight and fed complete diet. $1 / 2$ BA genotype presented higher percentage of ether extract in longissimus dorsi muscle compared with that of the other genotypes. The results obtained in the present study agree with those of Madruga et al. (2005), who observed higher percentage of ether extract in the muscle of crossbreed Boer animals compared with that of SRD animals.

Longissimus dorsi muscle from feedlot-finished animals had higher percentage of ether extract compared with that of animals finished on pasture. According to Lawrie (2005), usually, percentages of body and intramuscular fat increase with nutritional level (Table 5).

Females had higher percentage of ether extract in longissimus dorsi than males. According to Palacíos, Lozano and Martinez (2000), this result can be attributed to differences in the growth and development between females and males resulting from sexual hormone effects that influence growth speed and animal tissue components deposition (muscle, fat, and bone). In general, males have less intramuscular fat compared with females. Similar results have been found by Rodríguez et al. (2008) in Assaf lambs.

Ash percentage varied (1.05-1.09\%) and showed significant differences among the finishing systems. Feedlot kid goats had a higher value for ash compared with kid goats finished on pasture due to low moisture percentage and, consequently, higher protein and fat percentages.

\section{Conclusion}

Genotypes influenced physiochemical characteristics of goats' longissimus dorsi muscle. The best results were found in the meat of $1 / 2 \mathrm{BA}$ animals.

If the consumer's preference is greater tenderness and higher percentage of fat, female meat is the best option.

\section{References}

ABERLE, E. D. et al. Properties of fresh meat. In: ABERLE, E. D. et al. (Ed.). Principles of meat science. 4. ed. Dubuque: Kendal/Hunt Publishing Company, 1994. p. 109-116.

AMERICAN MEAT SCIENCE ASSOCIATION - AMSA. Research guideliness for cookery, sensory and instrumental tenderness measurement of fresh meat. Chicago: AMSA, 1995.

ASSOCIATION OF OFFICIAL ANALYTICAL CHEMISTS - AOAC. Official Methods of Analysis. Washington: AOAC, 2000.
BABIKER, S. A.; EL KHIDIR, I. A.; SHAFIE, S. A. Chemical composition and quality attributes of goat meat and lamb. Meat Science, v. 28, p. 273-277, 1990. http://dx.doi.org/10.1016/0309-1740(90)90041-4

BANSKALIEVA, V.; SAHLU, T.; GOETSCH, A. L. Fatty acid composition of goat muscles and fat depots: a review. Small Ruminant Research, v. 37, p. 255-268, 2000. http://dx.doi. org/10.1016/S0921-4488(00)00128-0

BESERRA, F. J. et al. Effect of age at slaughter on chemical composition of meat from Moxotó goats and their crosses. Small Ruminant Research, v. 55, p. 177-181, 2004. http://dx.doi.org/10.1016/j. smallrumres.2004.02.002

BESERRA, F. J. et al. Características químicas e físico-químicas da carne de caprinos SRD com diferentes pesos de abate. Revista TeC Carnes, v. 3, n. 2, p. 1-6, 2001.

CAÑEQUE, V. et al. Use of whole barley with a protein supplement to fatten lambs under different management systems and its effect on meat and carcass quality. Animal Research, v. 52, p. 271-285, 2003. http://dx.doi.org/10.1051/animres:2003020

DEL CAMPO, M. et al. Effects of feeding strategies including different proportion of pasture and concentrate, on carcass and meat quality traits in Uruguayan steers. Meat Science, v. 80, p. 753-760, 2008. http://dx.doi.org/10.1016/j.meatsci.2008.03.026

DHANDA, J. S.; TAYLOR, D. G.; MURRAY, P. J. The influence of goat genotype on the production of Capretto and Chevon carcasses. 2. Meat quality. Meat Science, v. 52, p. 363-367, 1999. http://dx.doi. org/10.1016/S0309-1740(99)00015-7

DHANDA, J. S.; TAYLOR, D. G.; MURRAY, P. J. Part 1. Growth. carcass and meat quality parameters of male goats: effects of genotype and liveweight at slaughter. Small Ruminant Research, v. 50, p. 5766, 2003. http://dx.doi.org/10.1016/S0921-4488(03)00112-3

DIAS, A. M. A. et al. Inclusão do farelo grosso de trigo na dieta e seu efeito sobre as propriedades físicas e sensoriais da carne caprins. Ciência e Tecnologia Alimentar, v. 28, n. 3, p. 527-533, 2008. http:// dx.doi.org/10.1590/S0101-20612008000300004

FRENCH, P. et al. The eating quality of meat of steers fed grass and/or concentrates. Meat Science, v. 57, p. 379-386, 2001.

FRENCH, P. et al. Meat quality of steers finished on autumn grass, grass silage or concentrate-based diets. Meat Science, v. 56, p. 173-180, 2000.

FRONING, G. W.; BABJI A, S.; MATHER, F. B. The effect of preslaughter temperatures, stress, struggle and anesthetization on color and textural characteristics of turkey muscle. Poultry Science, v. 57, n. 3 , p. $630-633,1978$.

HAMM, R. Biochemistry of meat hydration. Advances in Food Research, v. 10, n. 2, p. 335-443, 1960.

HAMM, R. Postmortem changes in muscle with regard to processing of hot-boned beef. Food and Technology, v. 36, p. 105, 1982.

HONIKEL, K. O. Reference methods for the assessment of physical characteristics of meat. Meat Science, v. 49, n. 4, p. 447-457, 1998. http://dx.doi.org/10.1016/S0309-1740(98)00034-5

IMMONEN, K.; RUUSUNEN, M.; PUOLANNE, E. Some effects of residual glycogen concentration on the physical and sensory quality of normal pH beef. Meat Science, v. 55, p. 33-38, 2000. http://dx.doi. org/10.1016/S0309-1740(99)00122-9

JOHNSON, D. D. et al. Breed type and sex effects on carcass traits. composition and tenderness of young goats. Small Ruminant Research, v. 17, p. 57-63, 1995. http://dx.doi.org/10.1016/09214488(95)00661-4

JOHNSON, D. D.; McGOWAN, C. H. Diet/management effects on carcass attributes and meat quality of young goats. Small Ruminant Research, v. 28, p. 93-98, 1998. http://dx.doi.org/10.1016/S0921-4488(97)00071-0 
KADIM, I. T. et al. An evaluation of the growth. carcass and meat quality characteristics of Omani goat breeds. Meat Science, v. 66, p. 203-210, 2003. http://dx.doi.org/10.1016/S0309-1740(03)00092-5

KANNAN, G.; KOUAKOU, B.; GELAYE, S. Color changes reflecting myoglobin and lipid oxidation in chevon cuts during refrigerated display. Small Ruminant Research, v. 42, p. 67-75, 2001. http:// dx.doi.org/10.1016/S0921-4488(01)00232-2

LAWRIE, R. A. Ciência da carne. 6. ed. Porto Alegre: Artmed Editora, 2005. 384 p.

MADRUGA, M. S. et al. Meat quality of Moxotó and Canindé goats as affected by two levels of feeding. Meat Science, v. 80, p. 10191023, 2008. http://dx.doi.org/10.1016/j.meatsci.2008.04.020

MADRUGA, M. S. et al. Características químicas e sensoriais de cortes comerciais de caprinos SRD e mestiços Boer. Ciência e Tecnologia Alimentar, v. 25, n. 4, p. 713-719, 2005. http://dx.doi.org/10.1590/ S0101-20612005000400014

MONTE, A. L. S. et al. Parâmetros físicos s sensoriais de qualidade da carne de cabritos mestiços de diferentes grupos genéticos. Ciência e Tecnologia Alimentar, v. 27, n. 2, p. 233-238, 2007. http://dx.doi. org/10.1590/S0101-20612007000200004

MTENGA, L. A.; KITALY, A. J. Growth performance and carcass characteristics of Tanzanian goats fed Chloris gayana hay with different levels of protein supplement. Small Ruminant Research, v. 3, p. 1-8, 1990. http://dx.doi.org/10.1016/0921-4488(90)90025-2

NATIONAL RESEARCH COUNCIL - NRC. Nutrient Requirements of Diary Cattle. Washington: National Academic Press, 2001.

PALACÍOS, G. L.; LOZANO, S. R.; MARTINEZ, S. E. V. Efecto del cruzamiento. sexo y dieta en la composición química de la carne de ovinos Pelibuey con Rambouillet y Suffolk. Veterinaria Mexico, v. 31, n. 1, p. 11-19, 2000.

PRATIWI, N. M. W.; MURRAY, P. J.; TAYLOR, D. G. Feral goats in Australia: A study on the quality and nutritive value of their meat. Meat Science, v. 75, p. 168-177, 2007. http://dx.doi.org/10.1016/j. meatsci.2006.06.026

PRIOLO, A.; MICOL, D.; AGABRIEL, J. Effects of grass feeding systems on ruminant meat colour and flavour. A review. Animal Research, v. 50, p. 185-200, 2001. http://dx.doi.org/10.1051/animres:2001125

PURCHAS, R. W. Effect of sex and castration on growth and composition. In: PEARSON. A. M.; DUTSON. T. R. (Eds.). Growth Regulation in Farm Animals. London: Elsevier Applied Science, 1991. v. 7 Advances in Meat Research, p. 203-254.

REALINI, C. E. et al. Effect of pasture vs. concentrate feeding with or without antioxidants on characteristics, fatty acid composition, and quality of Uruguayan beef. Meat Science, v. 66, p. 567-577, 2004. http://dx.doi.org/10.1016/S0309-1740(03)00160-8

RODRÍGUEZ, A. B. et al. Carcass and meat quality of Assaf milk fed lambs: effect of rearing system and sex. Meat Science, v. 80, p. 225230, 2008. http://dx.doi.org/10.1016/j.meatsci.2007.11.023

RYAN, S. M. et al. Effects of concentrate level on carcass traits of Boer crossbred goats. Small Ruminant Research, v. 73, p. 67-76, 2007. http://dx.doi.org/10.1016/j.smallrumres.2006.11.004
SAS (1999) - STATISTICAL ANALISYS SISTEM - SAS. SAS/STAT user's guide. Cary: 1999

SCHÖNFELDT, H. C. et al. Cooking-and juiciness-related quality characteristics of goat and sheep meat. Meat Science, v. 34, p. 381394, 1993. http://dx.doi.org/10.1016/0309-1740(93)90085-V

SCHROEDER, J. W. et al. Palatability. shelf-life and chemical differences between forage and grain-finished beef. Journal of Animal Science, v. 50, p. 582-589, 1980.

SHERIDAN, R.; HOFFMAN, L. C.; FERREIRA, A. V. Meat quality of Boer goat kids and Mutton Merino lambs. 1. Commercial yields and chemical composition. Animal Science, v. 76, p. 63-71, 2003.

SHRESTHA, J. N. B.; FAHMY, M. H. Breeding goats for meat production. 2. Crossbreeding and formation of composite population. Small Ruminant Research, v. 67, p. 93-112, 2007. http:// dx.doi.org/10.1016/j.smallrumres.2005.10.018

SILVA, D. J.; QUEIROZ. A. C. Análise de alimentos - Métodos químicos e biológicos. Viçosa: Universidade Federal de Viçosa, 2006. 235 p.

SIMELA, L.; WEBB, E. C.; FRYLINCK, L. Effect of sex. age. and pre-slaughter conditioning on $\mathrm{pH}$. temperature. tenderness and colour of indigenous South African goats. South African Journal of Animal Science, v. 34, p. 208-211, 2004.

SNIFFEN, C. J. et al. A net carbohydrate and protein system for evaluating cattle diets: II Carbohydrate and protein avaibility. Journal of Animal Science, v. 70, p. 3562-3577, 1992.

SWAN, J. E.; ESGUERRA, C. M.; FAROUK, M. M. Some physical. chemical and sensory properties of chevon products from three New Zealand goat breeds. Small Ruminant Research, v. 28, p. 273 280, 1998. http://dx.doi.org/10.1016/S0921-4488(97)00087-4

TSHABALALA, P. A. et al. Meat quality of designated South African indigenous goat and sheep breeds. Meat Science, v. 65, p. $563-$ 570, 2003. http://dx.doi.org/10.1016/S0309-1740(02)00249-8

TITI, H. H. et al. Comparative performance of Awassi lambs and Black goat kids on different crude protein levels in Jordan. Small Ruminant Research, v. 37, p. 131-135, 2000. http://dx.doi. org/10.1016/S0921-4488(99)00136-4

TODARO, M. et al. Effects of litter size and sex on meat quality traits of kid meat. Small Ruminant Research, v. 54, p. 191-196, 2004. http://dx.doi.org/10.1016/j.smallrumres.2003.11.011

VESTERGAARD et al. (2000) - VERTERGAARD, M. et al. Influence of feeding intensity, grazing and finishing feeding on meat and eating quality of young bulls and the relationship between muscle fibre characteristics, fibre fragmentation and meat tenderness. Meat Science, v. 54, p. 187-195, 2000. http://dx.doi.org/10.1016/ S0309-1740(99)00098-4

VESTERGAARD, M.; OKABJERG, N.; HENCKEL, P. Influence of feeding intensity. grazing and finishing feeding on muscle fiber characteristics and meat colour of semitendinosus. longissimus dorsi and supraspinatus muscles of young bull. Meat Science, v. 54, p. 177-185, 2000. http://dx.doi.org/10.1016/S0309-1740(99)00097-2

WEBB, E. C.; CASEY, N. H.; SIMELA, L. Goat meat quality. Small Ruminant Research, v. 60, p. 153-166, 2005. http://dx.doi. org/10.1016/j.smallrumres.2005.06.009 